\title{
Logistical challenges and distribution restrictions: analysis based in Niterói retailers perspective
}

\author{
Desafios logísticos e restrições na distribuição urbana de carga: \\ análise baseada na perspectiva dos varejistas de Niterói
}

\begin{abstract}
Thiago Delgado de Souza ${ }^{1}$ (D), Fernanda Silva Toledo ${ }^{1}$ (D), Renata Albergaria de Mello Bandeira ${ }^{1}$ (D), Vânia Barcellos Gouvêa Campos ${ }^{1}$ (D), Walmor Pereira de Andrade Neto ${ }^{1}$ (D)

${ }^{1}$ Instituto Militar de Engenharia - IME, Programa de Pós-graduação em Engenharia de Transportes - PPGT, Seção de Ensino de Engenharia de Fortificação e Construção - SE/2, Rio de Janeiro, RJ, Brasil. E-mails: engthiagodelgado@gmail.com; byfernandatoledo@gmail.com; re.albergaria@gmail.com; vaniabgcampos@gmail.com; walmorneto4@gmail.com
\end{abstract}

How to cite: Souza, T. D., Toledo, F. S., Bandeira, R. A. M., Campos, V. B. G., \& Andrade Neto, W. P. (2021). Logistical challenges and distribution restrictions: analysis based in Niterói retailers perspective. Gestão \& Produção, 28(2), e5087. https://doi.org/10.1590/1806-9649-2020v28e5087

\begin{abstract}
Intensive cargo movement in urban areas generates many vehicles in city centers. As a result, there are congestions increase and intensification of freight transport distribution system challenges. To overcome the difficulties, local traffic rules and restrictions for heavy vehicles are established, but they have an impact on carriers and shopkeepers activities, parcel little heard by surveys. The purpose of this paper is to analyze the difficulties in the receipt of goods in Niterói center, under the view of retailers. The data collected by survey in the study were evaluated trough descriptive statistics and multivariate analysis. The major impasses found were the lack of available places for unloading and intense traffic, and for logistical challenges non-opening to overnight delivery and security level in the receiving periods, due to the urban violence.
\end{abstract}

Keywords: Freight transportation; Logistics; Factor analysis.

Resumo: A intensa movimentação de cargas em áreas urbanas gera um grande número de veículos nos centros das cidades. Por conseguinte, há aumento dos congestionamentos e intensificação dos desafios no sistema de distribuição de carga. Para subverter tais dificuldades, são estabelecidas regras e restrições locais de circulação de veículos pesados. Porém estas causam impactos nas atividades das transportadoras e dos lojistas, parcela pouco ouvida pelas pesquisas. O objetivo do artigo é analisar quais são as maiores dificuldades no recebimento de mercadorias no centro de Niterói sob a visão dos varejistas. Os dados coletados por questionários aplicados in loco foram avaliados por estatística descritiva e análise multivariada. Os maiores impasses encontrados foram a baixa quantidade de vagas para a carga e descarga e o trânsito intenso, e quanto aos desafios logísticos foram observados a não abertura à entrega noturna e baixo nível de segurança durante o período da entrega, devido à violência urbana.

Palavras-chave: Transporte de carga; Logística; Análise fatorial.

Received Sep 3, 2018 - Accepted July 11, 2019

Financial support: None.

This is an Open Access article distributed under the terms of the Creative Commons Attribution License, which permits unrestricted use, distribution, and reproduction in any medium, provided the original work is properly cited. 


\section{Introduction}

According to a United Nations forecast, $70 \%$ of the world population will live in urban centers by 2050 (ONU, 2014). Associated with this urban population increase, there is a growth in goods and services demand and, consequently, more demand for urban freight transportation (UFT). Despite being fundamental to the cities survival and contributing to the local economy, UFT generates several negative socioeconomic and environmental impacts, especially in relation to traffic congestion intensification, damage to the road network, noise pollution and emission of air pollutants and greenhouse gases (GHG). In addition, it promotes costs increase and diminish the population safety, due to the increased number of accidents (Mckinnon et al., 2010; Oliveira et al., 2017).

The UFT represents about a quarter of the urban traffic in a city, requiring areas for loading/unloading, storage, conditioning, and packaging, which requires a large use of urban space (Dablanc, 2007). Therefore, to facilitate traffic flow, local rules and restrictions for the circulation of cargo vehicles in the city center are established, with access times defined according to the vehicle size, restriction zones and other measures that directly affect transportation operators. However, the negative influence of these measures also impacts the retailers, a sector that is often overlooked, but of equal importance for assessing the impacts of local restrictions (Furquim et al., 2018).

Sinay et al. (2004) and Dablanc (2007) highlighted singular expectations for retailers regarding UFT, such as, for example, punctual deliveries, as inventory reductions and sales losses due to the absence of products or customers are avoided. In this way, the maintenance of product quality and affordable prices is guaranteed, without prejudice to profitability. Van Duin et al. (2010) emphasized the importance that the logistical solutions for UFT meet the expectations of retailers, since their behavior directly affects the local dynamics (Taniguchi et al., 2016).

In this sense, this article aims to analyze the greatest difficulties in receiving goods, from the point of view of retailers who operate in urban centers. Thus, it is intended to discuss the main logistical solutions related to UFT for the problems identified by retailers in a medium-sized city. The focus of the study was Niterói (RJ) city center. According to IBGE (2017), cities with 100,000 to 500,000 inhabitants are considered medium-sized. The former capital of Rio de Janeiro state had a population of 497,883 inhabitants in 2017.

From this introduction, this work is divided into four sections. In section 2, a bibliographic review of the logistical problems and challenges related to UFT is presented. The research method adopted is set out in section 3 . In section 4 , the results and their respective analyses are discussed. Finally, in section 5, conclusions, limitations and suggestions for improving this work are presented.

\section{Urban freight transport}

According to Szołtyek (2014), the urban logistics scope should reduce bother associated with UFT, while supporting its economic and social development. Even with the advent of e-commerce, the need for product deliveries remains. Thus, due to congestions increase, the rationalization of people and goods traffic in urban areas has become one of the main problems for an effective city management, especially at the sustainable level (Hajduk, 2017). 
In face of environmental changes, accelerated urbanization and increasingly rudimentary infrastructure in cities, consistent methods are required to cover these challenges. An essential strategy is to develop local spatial development plans, related to roads and infrastructure, according to the current environmental order. On the other hand, transport related plans continue to include only items related to people movement, omitting freight transportation (Hajduk, 2017). As Dablanc (2007) had already noted, freight transportation is marginalized by local governments, which hold private companies responsible for the so-called "transportation and manufacture problems", and so the UFT is not organized efficiently (Anderson et al., 2005).

Currently, there are alternatives to reduce goods traffic, related to the traveled mileage from transport management and consolidation, minimizing the UFT impacts. Morganti \& Gonzalez-Feliu (2015) analyzed the role of political authorities that define traffic regulation and urban logistics measures for three years. Regarding access regulation, the authors concluded that the restrictions most commonly adopted by public authorities were on access of cargo vehicles to certain streets, period of the day when they can be used, types of vehicles allowed and efficiency of transportation occupancy rate. This type of restriction influences the movement pattern of cargo vehicles in an urban area, which depends on factors such as the existing transportation infrastructure, customer behavior, the size and weight of vehicles allowed to operate in an urban area and regulation of access and discharge (Allen et al., 2007). Insufficient installations of loading and unloading sites, for example, generate congestion and obstruction of usual traffic, which may increase the number of trips required for delivery (Sinay et al., 2004).

In this context, urban logistics solutions can be identified as coordinated actions between public authorities and private initiatives, so that both parties must identify their scope of action and plan a mutual strategy. Therefore, retailers also have responsibility, contributing to greater flexibility in delivery times and conditions (Pronello et al., 2016).

Furquim et al. (2018) listed the following measures related to goods receipt in urban areas to get along with the logistical challenges faced by retailers: security, street illumination, lack of space for loading and unloading, regulation and signage, noise, vehicles access restrictions, overnight deliveries, and monetary incentive by the government for receipts outside peak hours. Therefore, the analysis of urban logistics problems is a complex process, which requires a variety of data and information, development of models and evaluation schemes (Taniguchi et al., 2016). The purpose of this article is to use survey research as an evaluation scheme, collecting routine information from retailers.

\section{Method}

This research adopts survey as an investigation strategy with the objective of identifying the main difficulties in goods receipt faced by retailers, who operate in medium-sized urban centers. Thus, the research seeks to answer the following questions: (i) what is the impact of local restrictions on goods receipt in medium-sized urban centers? (ii) what are the main logistical challenges in these cities, from retailers point of view?

The research target population is formed by retailers from different sectors, that operate in Niterói city center, taken as an example to demonstrate the difficulties of goods receipt in medium-sized cities, in Brazil. It should be noted that a similar study was developed by Furquim et al. (2018) in Sorocaba (SP), a city that, like Niterói, is 
considered a medium sized urban center and regional capital. Therefore, it is possible to compare the results obtained by Furquim et al. (2018), in order to verify if there are similarities or divergences of the difficulties found in medium-sized Brazilian cities.

According to data from the Secretaria de Planejamento, Modernização da Gestão e Controle de Niterói (SEPLAG), there are 269 trade registrations in the city center. Thus, for a $95 \%$ confidence level and an acceptable error of $5 \%$, the minimum sample size of retailers was defined as 159 stores, based on the calculation proposed by Cochran (1985). Therefore, the study sample is non-probabilistic for convenience, comprising 160 retailers operating in Niterói center, in several sectors: food products; beverages and tobacco; fuels for motor vehicles; construction material; computer and communication equipment; equipment and articles for domestic use; cultural, recreational and sporting articles; pharmaceuticals, perfumery and cosmetics; medical, optical and orthopedic articles; new products not otherwise specified and used products. For companies stratification by trade sectors, the IBGE classification (2017) was adopted as basis.

Primary data sources were used, collected directly by questionnaires applied in the participating organizations. The collection instrument adopted in this research was the same used by Furquim et al. (2018). The collection instrument has eleven closed questions, structured in four blocks: (i) company characterization; (ii) goods receipt characterization; (iii) local restrictions; and (iv) logistical challenges. A scale from zero to ten was used to represent the perception level of the interviewees regarding local restrictions and logistical challenges, with ten representing a strong perception and zero a low perception for the restrictions. Regarding logistical challenges, the weights are inversely, so that zero represents a low perception, thus being a major problem (challenge). In total, 12 variables were analyzed, divided into local restrictions and logistical challenges, as shown in Table 1 . The reliability of the instrument was tested using Cronbach's alpha (alpha $=0.913$ ).

Data were collected on the spot in July and August 2017, through face-to-face interviews in commercial establishments in downtown Niterói. The collected data were consolidated and analyzed using descriptive and multivariate statistical procedures, using the Statistical Package for the Social Sciences (SPSS $®$ ) software, in addition to the Successive Intervals Method.

Table 1. Acronyms and variables definitions.

\begin{tabular}{|c|c|c|}
\hline Variable group & Variable & Question \\
\hline \multirow[t]{5}{*}{ Local restrictions } & LOCRECEB & Existence of a place for receiving goods \\
\hline & MOVMERC & $\begin{array}{l}\text { Difficulty of moving goods from the receiving point to the } \\
\text { desired location }\end{array}$ \\
\hline & TRANSINT & Transit during the receiving period \\
\hline & FLEX & Flexibility in receiving goods at another time \\
\hline & QNTDEMP & Number of employees assisting in receiving \\
\hline \multirow{7}{*}{$\begin{array}{l}\text { Logistical } \\
\text { challenges }\end{array}$} & ENTNOT & Agreement with night reception \\
\hline & INCENT & $\begin{array}{l}\text { Agreement to receive govt. incentive to receive goods } \\
\text { outside business hours }\end{array}$ \\
\hline & SEGCARG & Impact of security lack during delivery of goods \\
\hline & ILUMIN & Streets illumination \\
\hline & ESPDIS & Space available for loading and unloading \\
\hline & REGU & Satisfaction with regulations and signage \\
\hline & RUEM & Noises emitted during receipt \\
\hline
\end{tabular}




\section{Results}

In this section, the results and analysis obtained from the survey are presented.

\subsection{Study area characterization}

The city of Niterói is divided into five regions: East, North, Oceanic, Pendotiba and Praias da Baía. In addition, it comprises 51 neighborhoods in an area of $133,919 \mathrm{~km}^{2}$. The largest concentration of economic activities is in the Center and in Icaraí (PDDU, 2015), which are strategically located, in relation to the various modes of transport.

In the municipality of Niterói, according to Decree $n^{0}$ 11356/2013 (Niterói, 2013), published on February 19, 2013, the loading and unloading of heavy vehicles on main streets and avenues is prohibited on working days from 6 am to 10 am and from $4 \mathrm{pm}$ to 8 $\mathrm{pm}$, and, on Saturdays from 6 am to $10 \mathrm{am}$. The restriction covers, in the central region, the avenues Jansen de Melo, Marques do Paraná, Feliciano Sodré, Visconde do Rio Branco and the streets Barão do Amazonas, Visconde de Uruguai and Marechal Deodoro.

\subsection{Sample characteristics}

Figure 1 shows the spatial distribution of interviewed retailers and their respective sectors of activity, according to the IBGE classification (IBGE, 2017).

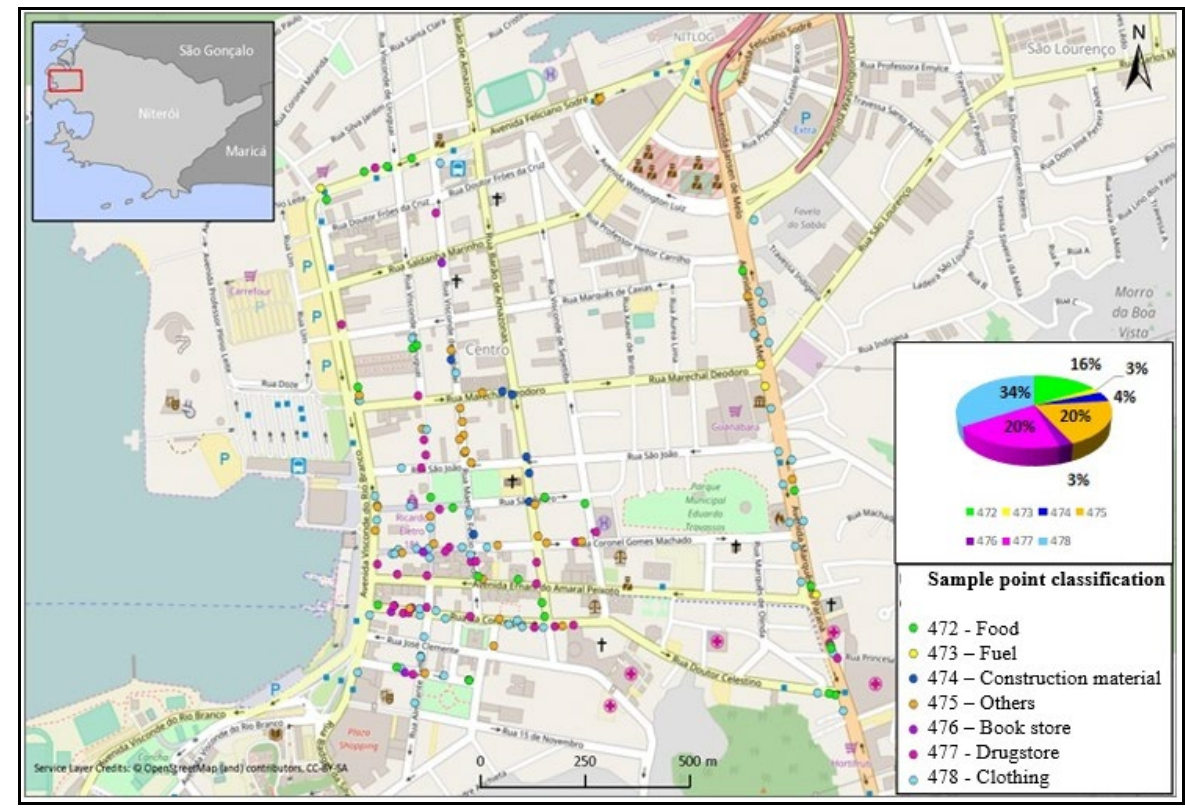

Figure 1. Sample spatial distribution by activity sector.

The questionnaire was applied directly to employees, managers and owners of different types of establishments. More than $50 \%$ of respondents were managers or owners/partners, therefore occupying more strategic positions, with broad vision and experience in the actuation sector. As for retailers size, micro enterprises (up to 10 employees) and small businesses (10 to 49 employees), from different sectors were interviewed (Table 2). 
Table 2. Number of employees by sector.

\begin{tabular}{lccc}
\hline Actuation sector & \multicolumn{2}{c}{ Number of employees } & \multirow{2}{*}{$\%$} \\
\cline { 2 - 3 } & $\mathbf{<}$ & $\mathbf{1 0 - 4 9}$ & \\
\hline 1 - Food products, beverages and tobacco & 18 & 8 & 0.16 \\
\hline 2 - Fuels for motor vehicles & - & 4 & 0.03 \\
\hline 3 - Construction material & 7 & - & 0.04 \\
\hline 4 - Computer and communication equipment; domestic use & 24 & 8 & 0.20 \\
\hline 5 - Cultural, recreational and sporting articles & 3 & 1 & 0.03 \\
\hline 6 - Pharmaceuticals, perfumery and cosmetics & 17 & 15 & 0.20 \\
\hline 7 - New products not otherwise specified and used products & 40 & 15 & 0.34 \\
\hline Total & 0.68 & 0.32 & 1 \\
\hline
\end{tabular}

\subsection{Goods receipt}

Retailers of Niterói center usually receive goods during the morning (55\%) and afternoon $(31 \%)$ periods. $6 \%$ of retailers stated that the receipt is made at lunchtime and $8 \%$ at night. The receipts occur predominantly on working days $(86 \%)$, but there is also a relevant quantitative on Saturdays $(12 \%)$. Only $1 \%$ of retailers receive goods on Sundays. Also, according to retailers, deliveries are made less than a seven-day period, so, there is usually more than one delivery per week, thus collaborating to intensify cargo movement in Niterói center.

Retailers showed a preference (59\%) for receiving goods in the morning (Table 3), due to the lower flow of customers at this time, which allows them to assign employees to receive products. However, there is a potential niche for making overnight deliveries in the sectors of cultural, recreational, and sporting articles and pharmaceuticals, perfumery, and cosmetics (Table 3 ). This practice should be encouraged for attenuating the traffic and improve circulation during peak hours.

Table 3. Preferred time for goods receipt.

\begin{tabular}{|c|c|c|c|c|c|}
\hline \multirow{2}{*}{ Actuation sector } & \multicolumn{5}{|c|}{ Reception time preference } \\
\hline & Morning & Afternoon & Lunch & Night & Dawn \\
\hline 1 - Food products, beverages, and tobacco & 0.70 & 0.10 & 0.03 & 0.07 & - \\
\hline 2 - Fuels for motor vehicles & - & 1.00 & - & - & - \\
\hline 3 - Construction material & 0.70 & 0.10 & - & - & - \\
\hline $\begin{array}{l}4 \text { - Computer and communication equipment; } \\
\text { domestic use }\end{array}$ & 0.74 & 0.17 & - & - & - \\
\hline 5 - Cultural, recreational, and sporting articles & 0.33 & 0.33 & - & 0.17 & 0.00 \\
\hline 6 - Pharmaceuticals, perfumery, and cosmetics & 0.51 & 0.11 & - & 0.24 & 0.08 \\
\hline $\begin{array}{l}7 \text { - New products not otherwise specified and used } \\
\text { products }\end{array}$ & 0.54 & 0.15 & 0.01 & 0.06 & 0.04 \\
\hline General & 0.59 & 0.16 & 0.01 & 0.08 & 0.03 \\
\hline
\end{tabular}

Regarding the vehicle types used to deliveries, Table 4 shows the distribution of these by activity sector. In all sectors, deliveries are mainly made by trucks. Only the food and fuel sectors have a good level of receipt by urban freight vehicles (UFV). It should be noted that deliveries made by motorcycles or bicycles have not been reported, which does not condone with the global trends in the use of sustainable modes of transport (Leonardi et al., 2012). 
Table 4. Vehicle type used in each sector.

\begin{tabular}{|c|c|c|c|c|c|c|c|}
\hline \multirow[b]{2}{*}{ Actuation sector } & \multicolumn{7}{|c|}{ Type of vehicle (\%) } \\
\hline & 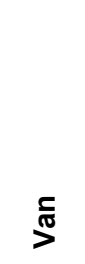 & $\stackrel{\rightleftarrows}{\leftrightarrows}$ & 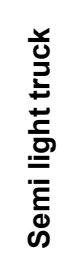 & 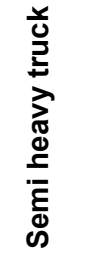 & 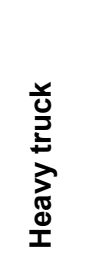 & 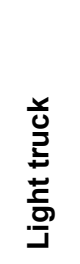 & 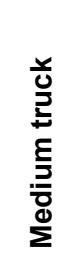 \\
\hline 1 - Food products, beverages and tobacco & 0.02 & 0.04 & 0.03 & - & - & 0.02 & 0.02 \\
\hline 2 - Fuels for motor vehicles & - & 0.01 & - & - & 0.01 & 0.01 & - \\
\hline 3 - Construction material & - & - & - & - & 0.01 & 0.01 & 0.01 \\
\hline $\begin{array}{l}4 \text { - Computer and communication equipment; } \\
\text { domestic use }\end{array}$ & 0.03 & - & 0.03 & 0.03 & 0.02 & 0.04 & 0.05 \\
\hline 5 - Cultural, recreational and sporting articles & - & - & 0.01 & - & - & - & - \\
\hline 6 - Pharmaceuticals, perfumery and cosmetics & 0.02 & 0.02 & 0.01 & 0.01 & 0.01 & 0.04 & 0.05 \\
\hline $\begin{array}{l}7 \text { - New products not otherwise specified and } \\
\text { used products }\end{array}$ & 0.07 & 0.05 & 0.07 & 0.03 & 0.03 & 0.08 & 0.06 \\
\hline General & 0.15 & 0.12 & 0.14 & 0.09 & 0.10 & 0.21 & 0.20 \\
\hline
\end{tabular}

Table 5 shows the parking types used for vehicles delivering goods to establishments, as well as their proportion in relation to the sample. It is noticed that $56 \%$ of retailers do not have an appropriate place for unloading goods, so transporters are obliged to park in more distant places and move the goods in auxiliary carts to the establishment. The fuel sector stood out positively, because in most cases had loading and unloading docks, and negatively, the building material stores, which in $86 \%$ of the cases used the common street parking lot to unload goods. It should also be noted that, in all sectors, most establishments do not have goods receipt schedule. According to the interviewees, orders are placed according to the stock reduction, without specific planning for this objective.

Table 5. Parking types for goods receipt.

\begin{tabular}{lccc}
\hline Actuation sector & \multicolumn{3}{c}{ Parking type } \\
\cline { 2 - 4 } & $\begin{array}{c}\text { Loading and } \\
\text { unloading } \\
\text { space }\end{array}$ & $\begin{array}{c}\text { Street } \\
\text { parking }\end{array}$ & $\begin{array}{c}\text { Parking } \\
\text { docks }\end{array}$ \\
\hline 1 - Food products, beverages and tobacco & 0.36 & 0.61 & 0.03 \\
\hline 2 - Fuels for motor vehicles & 0.33 & - & 0.67 \\
\hline 3 - Construction material & 0.14 & 0.86 & 0.00 \\
\hline $\begin{array}{l}\text { use } \\
\text { usemputer and communication equipment; domestic }\end{array}$ & 0.30 & 0.58 & 0.12 \\
\hline 5 - Cultural, recreational and sporting articles & 0.25 & 0.75 & - \\
\hline 6 - Pharmaceuticals, perfumery and cosmetics & 0.32 & 0.68 & - \\
\hline $\begin{array}{l}\text { p - New products not otherwise specified and used } \\
\text { products }\end{array}$ & 0.38 & 0.49 & 0.13 \\
\hline General & 0.34 & 0.56 & 0.10 \\
\hline
\end{tabular}




\subsection{Local restrictions impacts}

In general analysis of local restrictions, the existence of a place for receiving goods (average of 6.06) and transit (5.29) were the most impacting variables for retailers. On a smaller scale, appears the difficulty of moving goods (3.91). The flexibility to receive goods at another time (2.29) and the small number of employees (1.70) are low impact restrictions, due to the characteristics of commercial movement, which is greater during the day. In addition, most deliveries are carried out in an assisted manner by distributors.

Table 6 shows the correlation matrix for goods receipt local restrictions. All correlations were classified according to the hypothesis test proposed in CallegariJacques (2003), as significant at a $5 \%$ significance level.

Table 6. Correlation matrix between local restrictions.

\begin{tabular}{lccccc}
\hline & LOCRECEB & MOVMERC & TRANSINT & FLEX & QNTDEMP \\
\hline LOCRECEB & 1.000 & & & & \\
\hline MOVMERC & 0.515 & 1.000 & & & \\
\hline TRANSINT & 0.579 & 0.366 & 1.000 & & \\
\hline FLEX & 0.360 & 0.478 & 0.312 & 1.000 & \\
\hline QNTDEMP & $0.228^{* *}$ & 0.312 & $0.195^{* *}$ & 0.503 & 1.000 \\
\hline
\end{tabular}

Note: ${ }^{* *}$ represents weak correlation.

It can be seen, through Table 6, that local restrictions tend to be positively and correlated regularly with each other, excepting of two correlations that, although positive, are considered weak (Callegari-Jacques, 2003): (i) number of employees assisting in receiving and transit during the receiving period; (ii) number of employees assisting in receiving and existing place to receive goods. The highest degree of correlation was identified between the existence of a place for receiving goods and transit during the receiving period, followed by existing place to receive goods with the difficulty of moving it from the receiving point to the desired location, as occurred in Furquim et al. (2018).

To group and identify the main local restrictions, factor analysis with varimax rotation was used. In the analyzed set, the $\mathrm{KMO}$ was 0.724 and Bartlett's sphericity test showed a significance level of 0.000 , so can be inferred that there is a correlation between the variables. In addition, two components followed the Guttman-Kaiser criterion of eigenvalue greater than 1 and explained $71.25 \%$ of the samples variability. Thus, two main associated groups were identified (Table 7): receiving area conditions; (ii) adaptation to changes in local logistics.

Table 7. Factor analysis of local restrictions.

\begin{tabular}{cc}
\hline Factor & Variables \\
\hline & LOCRECEB \\
1. Receiving area conditions & TRANSINT \\
\cline { 2 - 2 } 2. Adaptation to changes in local logistics & MOVMERC \\
\hline
\end{tabular}


From the perspective of factor analysis, in cohesion level order of the variables, the main logistical challenges refer to the receiving area conditions, followed by adaptation to changes in local logistics. The existence of a place for receipts is the main local constraint, both in multivariate and descriptive statistical analysis.

\subsection{Logistical challenges}

The predominant logistical challenges are the agreement with night reception (average of 1.48) and the space available for loading and unloading (average of 2.06), which corroborates with Allen et al. (2007). In fact, it was found, in field, that there are several street vendors on Coronel Gomes Machado street. In addition, there is also an extensive taxi rank on da Conceição street, which, together with street vendors, makes more difficult to receive goods. Overnight receipt is seen as something negative by most retailers $(80 \%)$, as the extra costs, associated with the human resources that must be assigned to receive the goods, are still an obstacle to overnight delivery. Respondents pointed out that, even if there were incentives for receipts outside of peak hours, there would be a reluctance by most retailers to receive goods during that period. On the other hand, this type of routine has already obtained social, economic, and environmental beneficial results, confirmed by Browne et al. (2012).

In a smaller scale of logistical challenges, appears the incentives to receive goods outside business hours (average of 2.43) and satisfaction with regulation and signage (2.83). The security lack (3.49) and streets illumination (3.94) during the delivery of goods are also impacting. More than $60 \%$ of respondents said that regulations and signage are not satisfactory, as well as illumination. The level of noise emitted during loading and unloading (average of 6.73) is, in the opinion of most shopkeepers, not a major factor in their businesses functioning.

Table 8 shows the correlation between logistical challenges. It is observed that, in retailers opinion, the possibility of overnight delivery is strongly correlated with government incentives for deliveries made outside business hours, as well as occurred in the study made by Holguín-Veras (2008). Regulations and signage are strongly correlated with the space available for loading and unloading.

Table 8. Correlation matrix between logistical challenges.

\begin{tabular}{|c|c|c|c|c|c|c|c|}
\hline & ENTNOT & INCENT & SEGCARG & ILUMIN & ESPDIS & REGU & RUEM \\
\hline ENTNOT & 1.000 & & & & & & \\
\hline INCENT & 0.689 & 1.000 & & & & & \\
\hline SEGCARG & $-0.015^{\star}$ & $-0.007^{\star}$ & 1.000 & & & & \\
\hline ILUMIN & $0.127^{*}$ & $0.109^{*}$ & 0.412 & 1.000 & & & \\
\hline ESPDIS & 0.431 & 0.303 & $-0.044^{*}$ & $0.190^{* *}$ & 1.000 & & \\
\hline REGU & $0.278^{* *}$ & $0.174^{* *}$ & $0.164^{* *}$ & 0.369 & 0.609 & 1.000 & \\
\hline RUEM & $0.116^{*}$ & $0.015^{*}$ & 0.349 & $0.289^{* *}$ & $0.270^{* *}$ & 0.304 & 1.000 \\
\hline
\end{tabular}

Note: Correlations with *are insignificant at a $5 \%$ level. **weak correlation

Analogously to local restrictions, factor analysis for logistical challenges was executed. In this case, the KMO was 0.638 and Bartlett's sphericity test showed a significance level of 0.000 . Three components explained $73.67 \%$ of the samples variability. Thus, three main associated groups were identified (Table 9): physical space receiving conditions; (ii) overnight deliveries; and (iii) surrounding conditions. 
Table 9. Logistical challenges factor analysis.

\begin{tabular}{lcccc}
\hline \multirow{2}{*}{ Variables } & \multicolumn{3}{c}{ Factorial load } & \multirow{2}{*}{ Commonalities } \\
\cline { 2 - 4 } & $\mathbf{1}$ & $\mathbf{2}$ & $\mathbf{3}$ & \\
\hline ENTNOT & 0.254 & $\mathbf{0 . 8 7 5}$ & 0.025 & 0.831 \\
\hline INCENT & 0.060 & $\mathbf{0 . 9 2 7}$ & 0.025 & 0.864 \\
\hline SEGCARG & -0.125 & -0.007 & $\mathbf{0 . 8 7 3}$ & 0.777 \\
\hline ILUMIN & 0.218 & 0.107 & $\mathbf{0 . 7 2 9}$ & 0.591 \\
\hline ESPDIS & $\mathbf{0 . 8 6 4}$ & 0.281 & -0.022 & 0.825 \\
\hline REGU & $\mathbf{0 . 8 3 2}$ & 0.097 & 0.252 & 0.765 \\
\hline RUEM & 0.405 & -0.068 & $\mathbf{0 . 5 7 8}$ & 0.503 \\
\hline Accumulated variance (\%) & 24.766 & 49.480 & 73.670 & \\
\hline Cronbach's Alpha (0-1) & 0.756 & 0.809 & 0.618 & $\mathrm{KMO}=0.638$ \\
\hline
\end{tabular}

According to Pestana \& Gageiro (2005), in factor analysis, the level of cohesion between variables is higher in the first factor and lower in the last. Thus, in variables cohesion order, the main logistical challenges refer to the physical space receiving conditions, followed by overnight deliveries. The surrounding conditions are the least impactful. The space available for loading and unloading was pointed out as the crucial logistical challenge, both by multivariate and descriptive statistical analysis.

\subsection{Successive interval method analysis}

The retailers perception of the attributes related to local restrictions was obtained by the scale of their impact. It can be inferred, from the scale, about the order of importance that respondents give to each attribute, however it is not possible to know how much one category is more important than the other (Providelo \& Sanches, 2011). The distance between two consecutive categories (degree of importance) is unknown and not uniform, requiring a procedure to transform categorical data into scalars, in order to assess the relative importance between the characteristics. For that, the Successive Intervals Method was developed by Guilford (1975) and used in transport scope by Correia \& Wirasinghe (2007) and Providelo \& Sanches (2011).

The Successive Interval Method was applied for local restrictions and their impacts on retailers (block 3 of the questionnaire), as well as for the logistical challenges faced by retailers (block 4 of the questionnaire), with the results shown in Table 10.

Table 10. Attribute value in the range from 0 to 1.

\begin{tabular}{lccccc}
\hline Local restrictions Average Range from $\mathbf{0}$ to $\mathbf{1}$ & $\begin{array}{c}\text { Logistical } \\
\text { challenges }\end{array}$ & Average & $\begin{array}{c}\text { Range from } \\
\mathbf{0} \text { to 1 }\end{array}$ \\
\hline LOCRECEB & 5.81 & 1.00 & ENTNOT & 5.13 & 0.44 \\
\hline MOVMERC & 5.31 & 0.56 & INCENT & 4.82 & 0.22 \\
\hline TRANSINT & 5.64 & 0.85 & SEGCARG & 5.12 & 0.44 \\
\hline FLEX & 4.74 & 0.07 & ILUMIN & 5.23 & 0.52 \\
\hline QNTDEMP & 4.66 & 0.00 & ESPDIS & 4.52 & 0.00 \\
\hline & & & REGU & 4.93 & 0.30 \\
\hline & & & RUEM & 5.90 & 1.00 \\
\hline & & ENTNOT & 5.07 & 0.40 \\
\hline
\end{tabular}


It is observed, through Table 10, that the respondents consider the "lack of place to receive goods (availability of vacancies)" as the most important attribute of the local restrictions block. In fact, it was the item of the greatest emphasis by the respondents. Then, greater relevance was attributed to "transit in the receiving period", probably because the location and delivery time occur mostly during business hours. The item with the least impact was the "number of employees assisting the receipt".

Table 10 also shows the normalized attributes from zero to one for logistical challenges. However, it must be considered that the Successive Intervals Method is used for a Likert scale type, in which the points go from five levels of total agreement to total disagreement. Therefore, a higher average would bring the category with the greatest impact. However, in this study block, an impact scale was used in which zero was assigned for the negative idea and ten for the positive idea, making a score of ten meaning that street illumination is ideal, so is the space available for loading and unloading and regulation and signaling is satisfactory. Based on this logic, the values are inverted to find those with the greatest impact.

Thus, the greatest impact in the logistical challenges block is attributed to the item "space available for loading and unloading", which is consistent with the analysis of the Successive Intervals Method in block 3 . Followed by "agreement to receive government incentive to receive goods outside business hours" and "regulation and signage" itself. The attribute with the lowest impact observed was "noises emitted during receipt", followed by "street illumination". Among the two, only illumination received complaints, but directed only to specific streets and not the main ones.

\subsection{Comparison of local restrictions and logistical challenges in Brazilian midsize cities}

As previously highlighted, this research instrument was also applied to analyze local restrictions and logistical challenges faced by retailers for goods receipt in Sorocaba by Furquim et al. (2018). In Sorocaba, the main local restrictions observed were existence of a place for receiving goods and the difficulty of moving them from the receiving point to the desired location. In Niterói city, the existence of a place for receiving goods was also the main local restriction, but in the background the transit during the receiving period was highlighted.

It is noticed that the main problem faced in medium-sized cities in relation to local restrictions on goods receipts coincides. Coupled with this, the restrictions "flexibility in receiving goods at another time" and "number of employees assisting in receiving" appear in the same order of importance, according to retailers. The only difference between the cities of Sorocaba and Niterói was the difficulty of moving goods and transit during the receiving period, respectively. This is justified by the fact that Niterói has a vehicle-per-inhabitant-area ratio approximately twice than Sorocaba does, so, the Rio de Janeiro city has a higher vehicle networks density, despite its fleet being smaller than São Paulo city.

Regarding logistical challenges, the agreement with night reception and the space available for loading and unloading were considered decisive in both cities. On the other hand, streets illumination and noises emitted during receipt were the least worrisome elements for retailers. In the city of Sorocaba, retailers are more concerned with the impact of security lack in receiving cargo than the government incentive for deliveries outside business hours and satisfaction with regulations and signage. In the city of Niterói, the interviewees showed greater apprehension with the government 
incentives for deliveries outside business hours, then the regulations and signage and security lack during the receiving of goods.

It is noteworthy that, despite the differences in relation to logistical challenges, the main results were maintained in both surveys. According to statistical data from the Secretaria Pública do Estado de São Paulo Public (São Paulo, 2018), in 2017, there were 124 cargo thefts in the Sorocaba region. In contrast, in the same period, Niterói region recorded 90 occurrences of this type (ISP, 2018). Historically, the region of Rio de Janeiro municipality has a lower cargo theft rate than São Paulo. These data support the difference in the concern of retailers about logistical challenges.

\section{Conclusions}

This article aimed to identify the main logistical obstacles to the retail sector, answering: what is the impact of local restrictions on goods receipt in medium-sized urban centers? what are the main logistical challenges in these cities, from retailers point of view? To answer these questions, the survey approach applied directly to 160 shopkeeper units in Niterói (RJ) city center was used.

Shopkeepers, in general, consider the security in goods receipts important, including prefer it, even if exist government monetary incentives for deliveries outside business hours. Safety was just not considered significant by the construction materials and cultural, recreational, and sporting articles sectors.

The retailers showed a negative perception of $80 \%$ to nightly goods receipts. In general, the costs associated with extra human resources to receive goods outside business hours is the main objection to overnight receipt, even if there were government incentives to do so and effective results proven in other literature studies.

For the delivery of goods, mostly trucks of different tonnages were used, which does not corroborate with the global trend of sustainable delivery vehicles, such as bicycles, tricycles, and electric vehicles. Thus, the lack of awareness on companies part that make the deliveries stands out, as well as the lack of government incentives.

The field research allowed to see the importance of a greater adequacy to specific loading and unloading locations and the number of vacancies available, as it does not meet the shopkeepers demand. This leads to the improper use of street parking or even deliveries of goods in high traffic flow. As a result, carriers are often unable to deliver on the scheduled day or make a greater journey searching for specific places for loading and unloading. The existence of many places for taxis parking and hawkers around the streets also causes inconvenience to shopkeepers. It is expected that survey results encourage the review of urban freight mobility in Niterói center.

\section{References}

Allen, J., Thorne, G., \& Browne, M. (2007). BESTUFS good practice guide on urban freight transport (84 p.). The Netherlands: Bestufs.net

Anderson, S., Allen, J., \& Browne, M. (2005). Urban logistics: how can it meet policy makers sustainability objectives? Journal of Transport Geography, 13(1), 71-81. http://dx.doi.org/10.1016/j.jtrangeo.2004.11.002.

Browne, M., Allen, J., Nemoto, T., Patier, D., \& Visser, J. (2012). Reducing social and environmental impacts of urban freight transport: a review of some major cities. Procedia: Social and Behavioral Sciences, 39, 19-33. http://dx.doi.org/10.1016/j.sbspro.2012.03.088.

Callegari-Jacques, S. M. (2003). Bioestatística: princípios e aplicações. Porto Alegre: Artmed. 
Cochran, W. (1985). Sampling techniques (2nd ed.). Boston: John Wiley \& Sons.

Correia, A. R., \& Wirasinghe, S. C. (2007). Development of level of service standards for airport facilities: application to São Paulo International Airport. Journal of Air Transport Management, 13(2), 97-103. http://dx.doi.org/10.1016/j.jairtraman.2006.10.002.

Dablanc, L. (2007). Good transport in large european cities: difficult to organize, difficult to modernize. Transportation Research Part A, Policy and Practice, 41(3), 280-285. http://dx.doi.org/10.1016/j.tra.2006.05.005.

Furquim, T. S. G., Vieira, J. G. V., \& Oliveira, R. M. (2018). Restrições de carga urbana e desafios logísticos: percepção de varejistas e motoristas em Sorocaba. Transportes, 26(1), 142-156. http://dx.doi.org/10.14295/transportes.v26i1.1354.

Guilford, J. P. (1975). Psychometric methods (2nd ed.). London: Mc-Graw Hill Publishing Co.

Hajduk, S. (2017). Bibliometric analysis of publications on city logistics in international scientific literature. Procedia Engineering, 182, 282-290. http://dx.doi.org/10.1016/j.proeng.2017.03.194.

Holguín-Veras, J. (2008). Necessary conditions for off-hour deliveries and the effectiveness of urban freight road pricing and alternative financial policies in competitive markets. Transp. Research A, 42(2), 392-413. http://dx.doi.org/10.1016/j.tra.2007.10.008.

Instituto Brasileiro de Geografia e Estatistica - IBGE. (2017). Infográfico: dados gerais do município. Retrieved in 2018, February 22, from https://cidades.ibge.gov.br/

Instituto de Segurança Pública - ISP. (2018). Estatísticas de segurança, séries históricas por município desde janeiro 2014 (números absolutos). Retrieved in 2018, April 12, from http://www.ispdados.rj.gov.br/estatistica.html

Leonardi, J., Browne, M., \& Allen, J. (2012). Before-after assessment of a logistics trial with clean urban freight vehicles: a case study in London. Procedia: Social and Behavioral Sciences, 39, 146-157. http://dx.doi.org/10.1016/j.sbspro.2012.03.097.

Mckinnon, A., Cullinane, S., \& Browne, M. (2010). Green logistics: improving the environmental sustainability of logistics (Vol .1). Londres: Kogan Page.

Morganti, E; Gonzalez-Feliu, J. (2015). City logistics for perishable products. The case of the Parma's Food Hub. Case Studies on Transport Policy, 3(2), 120-128. http://dx.doi.org/10.1016/j.cstp.2014.08.003.

Niterói. Prefeitura Municipal. (2013). Decreto $n^{\circ} 11.356 / 2013$. Dispõe sobre o horário de carga e descarga de veículos pesados no Município de Niterói. Niterói, RJ: Diário Oficial de Niterói.

Oliveira, C. M., Albergaria De Mello Bandeira, R., Vasconcelos Goes, G., Schmitz Gonçalves, D. N., \& D'Agosto, M. D. A. (2017). Sustainable vehicles-based alternatives in last mile distribution of urban freight transport: a systematic literature review. Sustainability, 9(8), 1324. http://dx.doi.org/10.3390/su9081324.

Pestana, M. H., \& Gageiro, J. N. (2005). Análise de dados para ciências sociais: a complementariedade do SPSS. (4a ed.). Lisboa: Editora Sílabo.

Plano Diretor de Desenvolvimento Urbano - PDDU. (2015). Leitura técnica da revisão do Plano Diretor de Desenvolvimento Urbano de Niterói: Caderno de Mapas. Niterói: Prefeitura Municipal.

Pronello, C., Camusso, C., \& Valentina, R. (2016). Last mile freight distribution and transport operators's needs: which targets and challenges? In World Conference on Transport Research - WTCTR. Shangai.

Providelo, J. K., \& Sanches, S. P. (2011). Roadway and traffic characteristics for bicycling. Transportation, 38(5), 765-777. http://dx.doi.org/10.1007/s11116-011-9353-x.

São Paulo. Secretaria da Segurança Pública - SSP. (2018). Dados estatísticos do Estado de São Paulo, região - Sorocaba. Retrieved in 2018, April 12, from http://www.ssp.sp.gov.br/Estatistica/Mapas.aspx 
Sinay, M. C. F., Campos, V. B. G., Dexheimer, L. \& Novaes, A. G. (2004). Distribuição de carga urbana: componentes, restrições e tendências. Rio de Janeiro: Rio de Transportes II.

Szołtysek, J. (2014). Perspectives of city logistics. Logistyka, 4, 7-10.

Taniguchi, E., Thompson, R. G., \& Yamada, T. (2016). New opportunities and challenges for city logistics. Transportation Research Procedia, 12, 5-13. http://dx.doi.org/10.1016/j.trpro.2016.02.004.

United Nations - ONU. (2014). World urbanization prospects. Economic \& social affairs. USA: ONU.

Van Duin, J. H. R., Quak, H., \& Muñuzuri, J. (2010). New challenges for urban consolidation centers: a case study in 441 The Hague. Procedia: Social and Behavioral Sciences, 2(3), 6177-6188. http://dx.doi.org/10.1016/j.sbspro.2010.04.029. 